\title{
Phytochemical Constituents of Some Vegetables
}

\author{
Md. Abu Hasan Howlader, Md. Shamim Iqbal, S. M. Sirajul Islam and M. A. Quader* \\ Department of Chemistry, Dhaka University, Dhaka-1000, Bangladesh
}

(Received : 24 March 2012; Accepted : 10 February 2013)

\begin{abstract}
Alkaloids, terpenoids, tannins, saponins, phlobatannins, flavonoids, steroids, cardiac glycosides, sugar molecules, and amino acid distribution in four vegetables of Bangladesh origin belonging to the family of Cucurbitaceae were assessed and compared. The vegetables investigated were Luffa acutangula (Jhingga), Luffa cylindrica (Dhundul), Trichosanthes anguina (Chichingga) and Tricosanthes dioica (Potol).
\end{abstract}

Keywords: Vegetables, Luffa acutangula, Luffa cylindrica, Trichosanthes anguina, Tricosanthes dioica, Medicinal activity.

\section{Introduction}

The vegetable samples investigated in this study are widely cultivated in different parts of the Indian subcontinent, and the fruits are taken as vegetables. Literature survey revealed the presence of different compounds in individual plants. $L$. acutangula fruit was shown to contain cucurbetacin B and E and oleanalic acid while the presence of saturated and unsaturated fatty acids palmitic, stearic, oleic, linoleic and traces of lignoceric acid were encountered in its seeds ${ }^{1}$. From L. cylindrica fruit, isolation of two fibrinolytic saponins lucyosides $\mathrm{N}$ and $\mathrm{P}$, and two triterpenoid saponins $3-O-[\beta$-D-glucopyranosyl]-hederyenin-28- $O-\beta$-D-

glucopyranoside (lucyoside E) and 3-O-[ $\beta$-D-glucopyranosyl]-gypsogenin-28- $O-\beta$-D-glucopyranoside (lucyoside F) was reported ${ }^{2,3}$ while its seeds were found to contain palmitic, stearic, oleic, linoleic, linolenic, margaric, arachidonic acids, and also rhamnose, fructose, glucose and galactose ${ }^{4}$. From the seeds of $T$. anguina, a novel glycoside 5,7- dihydroxy-6-methoxy flavones-5-O- $\alpha$-L-rhamnopyranoside was isolated ${ }^{5}$. It also contain ascorbic acid while its mineral and vitamin contents are calcium, magnesium, potassium, phosphorus, iron, substantial amount of carotene, little thiamine, riboflavin and niacin ${ }^{6,7}$. A steroidal saponin $24-\alpha$-methyl-20-ene-7-hydro-stigmast- $8 \beta$ :14 $\beta$-di-3- $O-\beta$-Dxylofuranoside was isolated from $T$. dioica ${ }^{8}$. It was reported to contain vitamin-A, tannins, saponins, free amino acids and 5-hydroxytryptamine, while seed extract contained 7oxidihydrokarounidol-3-benzoate, elaeostearic, linoleic, oleic and saturated acids ${ }^{9,10}$.

L. acutangula, L. cylindrica, T. anguina and T. dioica are also used as medicine. All the vegetable species have been found to be active for the biosynthesis of steroidal molecules which have structure like cholesterol and are thought to have the capacity of lowering plasma cholesterol and LDL cholesterol ${ }^{11}$. Their various medicinal activities are given in Table 1. Surprisingly, these vegetables of Bangladesh origin did not receive significant scientific attention here in Bangladesh. Since weather and soil have profound influence towards the generation of small molecules, the present research is likely to find results different to those of previous findings.

Table 1. Review of the various medicinal uses of the studied vegetables of Cucurbitaceae family

\begin{tabular}{|c|c|}
\hline Species & Medicinal Activity \\
\hline L. acutangula & $\begin{array}{l}\text { The dried powder of fruit is used in the form of snuff in jaundice while the seed posses emetic, } \\
\text { expectorant, and demulcent property }{ }^{12} \text {. It is also proved as CNS depressant used traditionally in } \\
\text { insect bites by tribes of Western Maharashtra, India }{ }^{13} \text {. It also has potent } \alpha \text {-glucoside (an enzyme } \\
\text { responsible for breakdown of carbohydrates in intestine) inhibitory effect }{ }^{14} \text {. }\end{array}$ \\
\hline L. cylindrica & $\begin{array}{l}\text { The fruit is used to treat skin disease, and also good for liver, lungs, heart and stomach; having a } \\
\text { cooling effect on the body }{ }^{15} \text {. In Chinese medicine the inner skeleton of the dried fruit is used to treat } \\
\text { pain in the muscle and joints, chest and abdomen }{ }^{16} \text {. The fruit is also used as diuretic }{ }^{17,18} \text {. The seed } \\
\text { have been used in the treatment of asthma, sinusitis and fever }{ }^{19} \text {. It is also reported to contain a } \\
\text { potential therapeutic agent for the treatment of } \text { AIDS }^{20} \text {. }\end{array}$ \\
\hline T. anguina & $\begin{array}{l}\text { It is reported to be used in heart disorder, jaundice, fevers, alopecia, purgative, as an emetic, in } \\
\text { constipation }{ }^{7} \text {. The seeds are used as an anthelmintic and antidiarrhoeic and also used for treatment of } \\
\text { biliousness and syphilis }{ }^{21} \text {. }\end{array}$ \\
\hline T. dioica & $\begin{array}{l}\text { Leaves and fruits are used for treating alcoholism and jaundice }{ }^{22} \text {. It possess blood sugar, serum } \\
\text { cholesterol, high density lipoprotein, phospholipids and triglyceride lowering activity }{ }^{23,24} \text {. The leaves, } \\
\text { fruits and seeds also show antibacterial activity }{ }^{25} \text {. }\end{array}$ \\
\hline
\end{tabular}

*Author for Correspondence, e-mail: uromman@yahoo.com 


\section{Materials and Methods}

\section{Plant materials}

The vegetables were collected from Karwan Bazar, Dhaka. All the samples were identified and voucher specimen that contains identification characteristics of each sample was submitted to the herbarium for future reference. Vegetables were cleaned with water, chopped into small pieces, dried under shade for several days and then dried in an oven at reduced temperature (not more than $38.0{ }^{\circ} \mathrm{C}$ ) to make it suitable for grinding purpose. After grinding the coarse powder were stored in air-tight container with marking for identification and kept in cool, dark and dry place for future use.

Chemicals used

Petroleum Ether (PE, $40-60^{\circ} \mathrm{Cfraction}$ of petrol collected upon distillation), Ethyl Acetate (EA, distilled), methanol, ferric chloride, dil. hydrochloric acid, ammonia solution, acetic anhydride, chloroform, vanillin, conc. sulfuric acid (all of Merck), Dragendroff's reagent (prepared in lab.), glacial acetic acid, butanol, ethanol(distilled), silver nitrate, sodium hydroxide(Merck), sodium thiosulphate, and ninhydrin (Merck).

\section{Cold extraction and TLC behavior}

$3.0-4.0 \mathrm{~g}$ of the powder of each sample was kept submerged in separate test tubes in $\mathrm{PE}, \mathrm{EA}, \mathrm{MeOH}$ : water $(80: 20)$. Each test tube was stoppered with cork and allowed to stand for 48 hours with occasional stirring. Then each of the extractives was subjected to TLC examination (silica gel), and results were presented in Table 2 .

Table 2. TLC behavior of different extracts (cold) of each vegetable studied

\begin{tabular}{|c|c|c|c|c|}
\hline \multirow{3}{*}{ Vegetables } & \multirow{3}{*}{ Extracts } & \multirow{3}{*}{ Developing Solvent } & \multicolumn{2}{|c|}{ TLC Pattern } \\
\hline & & & \multicolumn{2}{|c|}{ Vaniline- $\mathrm{H}_{2} \mathrm{SO}_{4}$} \\
\hline & & & Spot(s) & Color \\
\hline \multirow{3}{*}{ L. acutangula } & $\mathrm{PE}$ & PE : EA (98:2) & 2 & pink \\
\hline & EA & PE : EA $(95: 5)$ & 3 & black \\
\hline & MeOH-Water & $\mathrm{CHCl}_{3}+$ few drops of $\mathrm{MeOH}$ & 2 & black \\
\hline \multirow{3}{*}{ L. cylindrical } & $\mathrm{PE}$ & PE : EA $(98: 2)$ & 3 & Green black \\
\hline & EA & PE : EA (95:5) & 4 & black \\
\hline & MeOH-Water & $\mathrm{CHCl}_{3}+$ few drops of $\mathrm{MeOH}$ & 2 & Black \\
\hline \multirow{3}{*}{ T. anguina } & $\mathrm{PE}$ & PE : EA (98:2) & 2 & yellow \\
\hline & EA & PE : EA $(95: 5)$ & 3 & black \\
\hline & MeOH-Water & $\mathrm{CHCl}_{3}+$ few drops of $\mathrm{MeOH}$ & 2 & Blue \\
\hline \multirow{3}{*}{ T. dioica } & $\mathrm{PE}$ & PE : EA $(98: 2)$ & 3 & yellow \\
\hline & EA & PE : EA $(95: 5)$ & 3 & bluish \\
\hline & MeOH-Water & $\mathrm{CHCl}_{3}+$ few drops of $\mathrm{MeOH}$ & 2 & brown \\
\hline
\end{tabular}

\section{Hot extraction}

The extraction was carried out by taking 250.0 g powder of each vegetable in Soxhlet apparatus using three different solvent systems petroleum ether $\left(60-80^{\circ} \mathrm{C}\right)$, EA $\left(60-80^{\circ} \mathrm{C}\right)$, $\mathrm{MeOH}$ : water (80:20) successively. The extracts were then concentrated by rotary vacuum evaporator and the individual extract was used for investigations. Color and consistency of those extracts are given in Table 3.

\section{Phytochemical screening}

Chemical tests were carried out on the different extracts using standard procedures to identify the constituents as described $^{26,27,28}$.

\section{Test for alkaloids}

$2.0 \mathrm{~mL}$ of each extract and $0.2 \mathrm{~mL}$ of dilute hydrochloric acid were placed in a test tube and then $1.0 \mathrm{~mL}$ of Dragendroff's reagent was added. 


\section{Test for tannins}

$2.0 \mathrm{~mL}$ of each extract was taken in a test tube. A few drops of $0.1 \%$ ferric chloride was added and observed for brownish green or blue-black coloration.
Test for phlobatannins

$2.0 \mathrm{~mL}$ extract of each vegetable sample was boiled with $1 \%$ aqueous $\mathrm{HCl}$, and observed for the deposition of red precipitate.

Table 3. Color and consistency of successive extract (hot) of the vegetables under investigation

\begin{tabular}{|c|c|c|c|}
\hline \multirow[t]{2}{*}{ Vegetables } & \multirow[t]{2}{*}{ Extracts } & \multicolumn{2}{|c|}{ Parameters } \\
\hline & & Color & Consistency \\
\hline \multirow[t]{3}{*}{ L. acutangula } & $\mathrm{PE}$ & Green & Viscous \\
\hline & EA & Greenish & Viscous \\
\hline & $\mathrm{MeOH}:$ Water $(80: 20)$ & Brownish yellow & Sticky \\
\hline \multirow[t]{3}{*}{ L. cylindrical } & $\mathrm{PE}$ & Yellowish green & Viscous liquid \\
\hline & EA & Greenish & Viscous \\
\hline & $\mathrm{MeOH}:$ Water $(80: 20)$ & Brownish & Sticky \\
\hline \multirow[t]{3}{*}{ T. anguina } & $\mathrm{PE}$ & Yellowish & Viscous liquid \\
\hline & EA & Yellowish green & Viscous \\
\hline & $\mathrm{MeOH}:$ Water $(80: 20)$ & Dark brown & Thick and sticky \\
\hline \multirow[t]{3}{*}{ T. dioica } & $\mathrm{PE}$ & Brown & Viscous \\
\hline & EA & Brownish black & Viscous \\
\hline & $\mathrm{MeOH}:$ Water $(80: 20)$ & Black & Thick and sticky \\
\hline
\end{tabular}

\section{Test for saponin}

$2.0 \mathrm{~mL}$ of each extract was taken in a test tube. $10.0 \mathrm{~mL}$ of the filtrate was mixed with $5.0 \mathrm{~mL}$ of distilled and shaken vigorously for a stable persistent froth. The frothing was mixed with three drops of olive oil and shaken vigorously, then observed for the formation of emulsion.

\section{Test for flavonoids}

$5.0 \mathrm{~mL}$ of each extract was heated with $10.0 \mathrm{~mL}$ of ethylacetate over a steam bath for 3.0 minutes. Then $4.0 \mathrm{~mL}$ of the filtrate was shaken with $1.0 \mathrm{~mL}$ of dilute ammonia solution. No yellow coloration was observed indicating a negative test for flavonoids.

\section{Test for steroids}

$2.0 \mathrm{~mL}$ of acetic anhydride was added to $2.0 \mathrm{~mL}$ methanolic extract of each sample with $2.0 \mathrm{~mL} \mathrm{H}_{2} \mathrm{SO}_{4}$. The colour changed from violet to blue or green in some samples indicating the presence of steroids.

\section{Test for terpenoids (Salkowski test)}

$5.0 \mathrm{~mL}$ of each extract was mixed in $2.0 \mathrm{~mL}$ of chloroform, and conc. $\mathrm{H}_{2} \mathrm{SO}_{4}(3.0 \mathrm{~mL})$ was carefully added to form a layer. A reddish brown colouration of the interface was formed to show positive results for the presence of terpenoids.

\section{Test for cardiac glycosides (Keller-Killani test)}

$5.0 \mathrm{~mL}$ of each extracts was treated with $2.0 \mathrm{~mL}$ of glacial acetic acid, containing one drop of $\mathrm{FeCl}_{3}$ solution. This was underplayed with $1.0 \mathrm{~mL}$ of conc $\mathrm{H}_{2} \mathrm{SO}_{4}$. A brown ring of the interface indicates a deoxysugar characteristic of carotenoides. A violet ring may appear below the brown ring, while in the acetic acid layer, a greenish ring may form just gradually throughout thin layer.

\section{Test for amino acids (paper chromatography)}

Aqueous methanolic extract of each vegetable was applied on a Whatmann No-1 paper with standards. The paper was run in solvent system ( $\left.\mathrm{n}-\mathrm{BuOH}: \mathrm{AcOH}: \mathrm{H}_{2} \mathrm{O}=4: 1: 1\right)$ for 24 hours. Then the paper was taken out, dried in air and sprayed with ninhydrin (triketohydrindene hydrate) solution. Then it was observed for the appearance of spots which were compared with different standards under the same conditions. 
Table 4. Qualitative analysis of the phytochemical constituents of some vegetables

\begin{tabular}{|c|c|c|c|c|c|c|c|c|c|}
\hline Vegetables & Extract & Alkaloid & Tannin & $\begin{array}{l}\text { Phloba- } \\
\text { tannin }\end{array}$ & Saponin & Flavonoid & Steroid & Terpenoid & $\begin{array}{l}\text { Cardiac } \\
\text { glycoside }\end{array}$ \\
\hline \multirow{3}{*}{$\begin{array}{l}\text { L. } \\
\text { acutangula }\end{array}$} & PE & - & - & - & - & - & + & + & - \\
\hline & EA & - & + & - & - & + & + & + & - \\
\hline & $\begin{array}{l}\text { MeOH- } \\
\text { Water }\end{array}$ & - & + & - & + & + & + & + & + \\
\hline \multirow{3}{*}{$\begin{array}{l}\text { L. } \\
\text { cylindrica }\end{array}$} & $\mathrm{PE}$ & - & - & - & - & - & + & + & - \\
\hline & EA & - & + & - & + & + & + & + & - \\
\hline & $\begin{array}{l}\text { MeOH- } \\
\text { Water }\end{array}$ & - & + & - & + & + & - & - & + \\
\hline \multirow{3}{*}{$\begin{array}{l}T . \\
\text { anguina }\end{array}$} & $\mathrm{PE}$ & - & - & - & - & - & + & + & - \\
\hline & EA & + & + & - & + & - & + & + & - \\
\hline & $\begin{array}{l}\text { MeOH- } \\
\text { Water }\end{array}$ & - & + & - & + & + & - & - & + \\
\hline \multirow{3}{*}{$\begin{array}{l}T . \\
\text { dioica }\end{array}$} & $\mathrm{PE}$ & - & - & - & - & - & + & + & - \\
\hline & EA & - & + & - & + & + & + & + & - \\
\hline & $\begin{array}{l}\text { MeOH- } \\
\text { Water }\end{array}$ & + & + & - & + & + & - & - & + \\
\hline
\end{tabular}

$+=$ Presence of constituents; $-=$ Absence of constituents

Table 5. Result of sugar and amino acid analysis of the aqueous methanolic extracts of the fruits of the vegetables

\begin{tabular}{|l|l|l|}
\hline Vegetables & Sugar molecules & Amino acids \\
\hline L. acutangula & Glucose, glucoronic acid & Threonine, proline, alanine \\
\hline L. cylindrica & Glucose, fructose, galactose & Phenylalanine, glycine, tyrosine \\
\hline T. anguina & Glucose, arabinose & Glycine, tryptophan \\
\hline T. dioica & Glucose, arabinose & Glycine, alanine, glutamic acid \\
\hline
\end{tabular}

\section{Results and Discussion}

Results of preliminary TLC investigation of different extracts (of different solvents) of each vegetable are presented in Table 2. PE extracts of the vegetables were found to show 2-3 spots whereas EA extracts showed 3-4 spots for respective extract, and aq. methanolic extracts showed 2 spots in each case. TLC observation indicated the presence of different compounds.

Phytochemical screening revealed the presence of different types of compounds in the vegetables investigated, and results are summarized in Table 4 and Table 5. Tannins, saponins, flavonoids, steroids, terpenoids, and cardiac glycosides were present in all the vegetables. These types of compounds were known to show medicinal as well as physiological activity ${ }^{26}$. Alkaloid was found in T. anguina and T.dioica whereas phlobatannin was absent in all the vegetables. The present study is in conformity with Kalaskar Mohan G. et $\mathrm{al}^{29}$. about the presence of flavonoids, tannins, steroids, and the absence of alkaloids in L. acutangula but contradicts the observation of cardiac glycosides ${ }^{28}$. The presence of saponins, terpenoids, flavonoids in L. cylindrica was also reported by Qizhen Du et al. ${ }^{30}$. The isolation of various saponin from $L$. cylindrica was also reported previously ${ }^{2,3}$. Moreover, the present study reveals the presence of steroids, tannins and cardiac glycosides in $L$. cylindrica. The presence of glycoside in T. anguina is in conformity with the previous findings 5 . The presence of steroids, saponins and tannins was also reported by the previous workers ${ }^{8,9,10}$.

The present study also reveals the presence of various sugar molecules, and essential as well as non-essential amino acids in those vegetables which are presented in Table 5. Glucose was found in all the vegetables while arabinose was present in both $T$. anguina and $T$. dioica. Among the amino acids, glycine was present in all vegetable except $L$. acutangula. Presence of essential amino acids also proves the importance of those vegetables as food. Threonine in $L$. acutangula, phenylalanine in L. cylindrica, and typtophan in T. anguina were found as essential amino acids.

In the light of the detection of different important molecules like essential amino acids, flavonoids, cardiac glycosides, terpenoids, the physicians may find its use to the well being of people. Moreover, the results are believed to arouse interest among the scientists for further research. 


\section{References}

1. Rastogi, R. P., B. N. Mehrotra, 2001. Compendium of Indian medicinal plant, CSIR, Lakhnow, 5, 503-504.

2. Roem, Y., Y. Kazuko, A. Shigenobu; W. Jen-Der, N. Takao, O. Toru, 1991. Structure of two new fibrinolytic saponins from the seed of L. cylindrical. Fac. Pharm. Sci., TokushimaBurni Univ., Tokushima, Japan 770, Chem. Pharm. Bull., 39 (5), 1185-8 (Eng).

3. Zhapu, F., Z. Xianyi, X. Shuling, 1996. A new cerebrioside from L. cylindrical. Jiangxi Institute of Materia Medica, Nanchang, Peop. Rep. of China 330029, Tianran chanwn Yyanjiu Yu Kafia, 8(3), 20-25 (Ch.).

4. Joshi, S.S., R. K. Shrivastava, 1978. Chemical examination of L. cylindrica seeds. Dep. Chem. Cov. Coll. Eng. Tech., Raipur, India, Proc. Natl. Acad. Sci, India, Sect. A., 48(4), 211-14 (Eng).

5. Yadava, R.N., S. Yasmeen, 1994. An isoflavone glycoside from the seeds of T. anguina. Dep. Chem., Dr. H. S. Gour Univ., Sagar, 470003 India, Phytochemistry, 36(6), 1519-21 (Eng).

6. Rieko, I., A. Kimiko, I. Hiroko, A. Masato, I. Noriko, 2001. Suginami City Inst. Public Health, Japan, Suginamiku Eisci shikensho Nenpo, 19, 56-57 (Japan).

7. Bakhru, H.K., 1997. Herbs that heal, natural remedies for good health. Orient Paper Books $8^{\text {th }}$ ed. 230.

8. Saxena, V.K., R. K. Dave, 1995. A new steroidal saponin from T. dioica. Phytochemical Laboratory, dr. Harisingh Gour Univ., sagar, 470003 India, Asian J. chem., 7(3), 490-4 (Eng).

9. Chopra, R.N., S. L. Nayar, I. C. Chopra, 2002. Glossary of Indian Medicinal plants, CSIR, New Delhi, p.340.

10. Toshihiro A., K. Yumico, K. Yoshimasa, K. Kunio, S. Thakur, T. Tamura, 1997. 7-oxidihydrokarounidol-3-benzoate and other triterpenes from the seeds of Cucurbitaceae. Phytochemistry, 46(7), 1261-1266.

11. Piiroenen, V., D. G. Lindsay, T. A. Miettien, J. Toivo, A. M. Lampi, 2000. J. Sci. of food and agriculture, 80, 939-966.

12. Kirtikar, K. R., B. D. Basu, 1987. Indian Medicinal plant, Internatioinal Book Distributers, Dehradun, India, 2(IV), 2315-2316.

13. Misar, A.V., A.S. Upadhye, 2004. CNS depressant activity of ethanol extract of Luffa Acutangula var. amara C.B. Clarke fruits in mice. Indian Journal of Pharmaceutical Science, 66(4), 463-465.

14. Andrade-Cetto, A., J. Becerra-Jimenez, R. CardenasVazquez-, 2008. Alfaglucosidase inhibitory activity of some Mexican plants used in the treatment of type-2 diabetes. $J$ Ethnopharcol, 116, 27-32.
15. Kirtikar, K.R., B. D. Basu, 1980. Indian Medicinal plants, published by Singh B and Singh M P. India, $2^{\text {nd }}$ ed., 1, 915917.

16. Duke, J. A., 2002. CRC Handbook of medicinal herbs, $2^{\text {nd }} e d$. 30-35.

17. Satyavathi, G.V., M. K. Raina, M. Sharma, 1976. Indian medicinal plants, ICMR, New Delhi, 2, 178.

18. Shah, C. S., K. D. Mody, 1971. J Res Ind. Med., 6 (1), 71.

19. Stephens, J.M., 2003. Ground Luffa. J. hortic Sci., 3, 19-21.

20. McGrath, M. S., S.E. Hwang, S.E. Caldwell, J. D. Liston, 1989. An inhibitor of human immunodeficiency virus replication in acutely and chemically infected cells of lymphocyte and mononuclear phagocyte lineage. Natl. Acad. Sci., 86, 2824-2848.

21. Rahman, A. H. M. M., N. Anisuzzaman, F. Ahmed, R. Islam, A. T. M. Naderuzzaman, 2008. J. App. Sci. Res., 4, 555.

22. Nadkarni, A. K., 1982. Indian Materia Medica, Bombay popular prakashan, Mumbai, 3, 1236-1237.

23. Chandrasekhor, B., B. Mukherjee, S. K. Mukherjee, 2008. Blood suger lowering effect of $\mathrm{T}$. Dioica Roxb. in experimental rat models. Inst. J. Cru. Drug. Res., 26, 102106.

24. Sharma, G., M. C. Pant, 1988. Preliminary observation on serum biochemical parameters of albino rabbits fed on $\mathrm{T}$. Dioica Roxb. Indian J. Med. Res., 87, 398-400.

25. Rai, P.K., S. Mehta, R. K. Gupta, G. Watal, 2010. A novel antimicrobial agent $T$. Dioica. Int. Journal of Pharma and Bio Sciences, 1(3), 1-9.

26. Sofowara, A., 1993. Medicinal plants and Traditional medicine in Africa. Spectrum Books Ltd, Ibadan, Nigeria, p. 289.

27. Trease, G. E., W. C. Evans, 1989. Pharmacognsy, Brailliar Tiridel Can. Macmillian publishers, 11th ed.

28. Harborne, J. B., 1973. Phytochemical methods, London. Chapman and Hall, Ltd., 49-188.

29. Kalaskar, M. G., S. J. Surana, 2010. (R C Patel Institute of Pharmaceutical Education \& Research, Shirpur, Dhule, MS,India), International Journal of Pharm Tech Research, 2, 1609-1614.

30. Du Qizhen, X. Y., L. Li, Y. Zhao, G. Jerz, P. Winterhalter, 2006. Antioxidant Constituents in the fruits of Luffa cylindrica (L.) Roem, J Agr. Food Chem., 54, 4186 - 4190. 